\title{
Competition Law in Pakistan and China: A Comparative Study
}

\author{
Nishan-E-Hyder Soomro ${ }^{1} \&$ Wang Yuhui ${ }^{1}$ \\ ${ }^{1}$ School of Law and Economic, Zhengzhou University, Zhengzhou, China. \\ Correspondence: Wang Yuhui, Deputy Dean at School of Law and Economic, Zhengzhou University, Zhengzhou, \\ China. E-mail: 550805852@qq.com
}

Received: October 20, 2020

Accepted: November 20, 2020

Online Published: December 14, 2020

doi:10.5539/jpl.v14n2p1

URL: https://doi.org/10.5539/jpl.v14n2p1

\begin{abstract}
The present study aims to make comparative analysis of competition law in Pakistan and China by analyzing the leniency programs that whether or not they are in accordance with market structure or not, and investigating the mechanism to evidences while applying leniency policies and its value in competition law. The study adopts qualitative data analysis in order to analyze the respective aims and objective. It is found out by this research that progressive and unconventional are very important to be taken by both countries in order to ingeniously enforce competition law. Although competition law is supposed to prevent anti competition rituals and practices by nurturing free and fair competition in the market. It promotes a greater competition in the market by safeguarding customers against inaccurate means, which are adopted by firms. Therefore, competition law can be regarded as highly essential for regulating businesses by ensuring producer and consumer welfare. It ultimately promotes healthy growth of the economy and social justice. While on the other hand, a huge budget is entailed by investigation procedures which have been regarded as a huge financial resources' loss by experts. In addition to this, there is also a greater risk of surcharges of violation, punishment and legal costs, which sometimes lead to harm corporate image. Moreover, the leniency programs in both Pakistan and China cover administrative liability only. Therefore, it is important to voluntarily comply with competition rules, regulations and laws, which would play an immensely significant role in minimizing the social costs which occur due to this law enforcement. Qualitative research methodology has been applied to the following article.
\end{abstract}

Keywords: Competition Law Pakistan, China Anti-Monopoly Law (AML), Competition Law Act 2010

\section{Introduction}

\subsection{Historical Background}

Pakistan's origins have been rooted in the Indus Valley Civilization - an ancient civilization in the world that dates back to at least 5,000 years. In second millennium B.C., fragments of this prehistoric culture got fused with migrant people like Indo-Aryan. Arabs (pioneers of Islam), Greeks, Persians, Turks, Afghans and Scythians consecutively invaded this region in succeeding centuries. Mughal Empire was flourishing in 16th and 17th centuries however in 18th century British got dominant over the region (Competition Policy Report, 2007). When British India was separated into a Hindu India and Muslim State of Pakistan (along with East and West sections) in 1947 many issues were never principally resolved. After separation, India and Pakistan fought two wars over disputed territory of Kashmir - in 1947-48 and in 1965. Consequently, India in 1971 started a third war by capitalizing on Pakistan's marginalization and discrimination against Bengalis in politics. Because of this East Pakistan seceded and emerged as a separate entity and nation of Bangladesh (Competition Policy Report, 2007). In February 2008, after President Musharraf's resignation, parliamentary elections were held in September 2008 where Asif Ali Zardari was elected to the presidency. The military leaders and Pakistan's government have been consistently fighting with domestic insurgents who are located mainly in the vicinity of tribal areas that are adjacent to Afghanistan's border. A nonpermanent seat in the 2012-2013 term of Security Council was assumed by Pakistan (Competition Act, 2010).

On the other hand, Communist Party of China (CPC) in December 1978 made a crucial decision of shifting their focus from their goal of 'class struggle' to a new era of 'economic development'. Subsequently then, China paved a way towards an incremental and a far-reaching reform that fundamentally changed a centrally-planned economy to a market-based one. China opened up its economy to participate in global markets through foreign investment. 11th December 2001 marked the day of formal integration into an international economic system through World Trade Organization (WTO) (Haq, 1974). This economic growth of China with such high sustained rate became 
quite remarkable since it grew in the umbrella of under-developed financial markets and a weak legal systemboth institutions are quite central to any economic development. China while embarking on the journey of opening up and economic reforms, their legal system was practically non-existent and was effectively obliterated during its cultural revolution (Allen et al, 2005). Since mid-1990s, China started attaching significance to the rule of law; established and improved their legal institutions for supporting and promoting economic reforms for developing their market economies (Donald, 2007). As part of all law-making efforts, a comprehensive competition law was enacted in 2007 - the Anti-Monopoly Law (AML). AML regulates exploitations of dominant market positions, mergers (denoted as the 'concentration of undertakings') and anticompetitive agreements (stated as 'monopoly agreements'), (Lubman, 2000), these conducts are altogether referred to as monopolistic conduct. AML's provisions have been tailored for dealing with China's specific matters, mainly, administrative monopoly (Donald, 2007). Administrative monopoly is abusing of administrative power that restricts competitions and is inclusive of administrative power impeding free flow of good in China's internal competition, market or in any particular sectors or industries (Allen, 2005). This article is aimed at scrutinizing following objectives:

1) To analyze the leniency programs in both china and Pakistan that whether or not they are in accordance with market structure or not.

2) To investigate the mechanism to evidences while applying leniency policies and its value in competition law.

There are five parts in the article. Part I provides an insight through introducing the topic. Part II provides review of already existing literature over that and methodology adopted in this paper. Part III emphasizes on different phases of China and Pakistan's competition law. Part III gives a framework of the law's salient features. Part IV suggests an institutional framework along with details of its powers, leniency policies, working mechanism and functions as per the law. Part V constitutes conclusion quite necessary for law's effective enforcement.

\section{Literature Review}

No literature has ever been produced over comparison of competition law in China and Pakistan. Therefore, this study can be called a new study of its own kind. However, the researchers have conducted research on competition law in China and Pakistan, but separately. According to Daudpota (2013), now in Pakistan there have been no major monopolies apart from some of the public sector utilities, pre 1970s era shows us the dominance of monopolies and cartels that were being controlled by few Pakistani families. It was the time when anti competition law wasn't introduced, and the whole economy of Pakistan was concentrated in the hands of roughly 20 family groups (Fatima, 2012). 2/3 of the industrial assets were held by these 20 groups collectively. Anti competition law brought many effective changes in the Pakistani economy, however, despite of some essential terms, regulations of CCP leniency regulations can be detailed further while incorporating limits, criteria, deadlines, permitting all interested parties to be aware of everything (L Nielson, 2018).

A policy of leniency policy, apart from creating deterrence for cartels and anti-competitive practices, brings about corrective behavior. The authorities, however, must be vigilant not to allow a perception among the business and legal communities that it is rewarding to wait until the Commission has decided the matter to present a leniency proposal, and not before. According to Huang (2008), there have been many positive developments in China due to AML, but there can also be found some important features of political and economic environment which becomes a great hurdle in competition law. First of them is the public as well as official concerns with regard to Chinese business' foreign dominance along with its strong wish to business which can compete global industries at global level (Wang, 2002).

\section{Methodology}

This research would employ qualitative data analysis in order to analyze, examine and compare anti monopoly law in Pakistan. For the purpose of analyzing and integrating what has already been known literature review is provided. Both primary and secondary sources are provided such as books, journal articles, and newspapers, official documents would be consulted to conduct this research.

\section{Competition Law in Pakistan: Phases of Progression}

\subsection{First Phase: 1960 s- Road to Mrtpo}

The Anti-Cartel Law Study Group was formulated to suggest and examine worthwhile measures and policies for preventing unreasonable growth of monopolies and restricting trade policies, whilst private sector was flourishing in the country. Government during that period did encourage capital formation in its private sector. In addition to this, policies were adopted for fulfilling aims like fiscal concessions, industrial credit and industrial licensing (Donald, 2007). The consequent result of this was concentration of power in the hands of very few family groups who dominated commercial, industrial, insurance and banking activities in their country. This trend of 
concentration of power created feeling of discontent within the disadvantageous group - detrimental to public interest. Hence, the Report of the Study Group ascertained occurrence of monopolies and cartels. Thus, advocating of anti-monopoly law was the need of hour (The Competition Ordinance No LII, 2007).

\subsection{Second Phase: 1970-2007 (Mrtpo)}

In 1970, first competition law was made statutory through 'Monopolies and Restrictive Trade Practices (Control and Prevention) Ordinance (MRTPO) 1970 (Khan et al., 2008). An organization i-e Monopoly Control Authority (MCA) was developed for administering this ordinance. Anti-Cartel Laws Study group provided recommendations on Monopolies and Restrictive Trade Practices (Control and Prevention) Ordinance. A draft was circulated by the government pertaining to this ordinance in budget of 1969-70 for public opinion. This drafted law gained popularity in various sectors particularly Chambers of Commerce, press, public and many industries (Khan et al., 2008). President and Chief Marshall Law Administrator took all comments into account while promulgating it in February 1970. As a modern and contemporary piece of legislation this ordinance got enacted and was divided into respective six chapters. Nonetheless, the changing national and global economic dynamics determined the inadequacy of MRTPO 1970. State monopolies did not come under the purview of MRTPO 1970 whereas private monopolies were subjected to bind with this law (Allen et al., 2005). Additionally, the term 'services' was limited: certainly, main areas of services were falling outside the ordinance's 'definition' clause. Only few services were being covered to regulate sectors such as; the Pakistan Telecommunication Authority (PTA) that was recognized by Pakistan Telecommunications (Reorganization) Act 1996 (XVII of 1996), Transmission and Distribution of Electric Power Act 1997 (XL of 1997), National Electric Power Regulatory authority formed under the supervision of Regulation of generation and Oil and Gas Regulatory Authority formulated under Oil and Gas Regulatory Authority Ordinance 2002 (XVII of 2002) (Competition Policy Report, 2007). Therefore, role of Monopoly Control Authority had been marginalized in the sectors as a sector regulator.

From 1971-80, following cases were dealt by MCA

\begin{tabular}{ll}
\hline Nature of Cases & No. of Cases \\
\hline Conversion of private limited companies into & 17 \\
public limited companies & \\
Divesture of excessive shareholdings & 4 \\
Registration of prohibited agreements & 19 \\
Total order passed & 408 \\
\hline
\end{tabular}

Only recommendations can be made by MCA to the government. These recommendations are made to regulate suitable actions of government for preventing and eliminating any undue concentrations of the economic power, monopoly power or any unreasonable restrictive trade practices (PLD SC, 2009). On the other hand, in practice these functions of giving any recommendations and advice had been hampered because businesses are not obligated under the purview of law.

From 1980-95, following cases were dealt by MCA

\begin{tabular}{ll}
\hline Nature of cases & No. of Cases \\
\hline Conversion of private limited companies into & 7 \\
public limited companies & \\
Divesture of excessive shareholdings & 6 \\
Inter corporate financing & 3 \\
Monopoly Power & 1 \\
Registration of prohibited agreements & 49 \\
Total order passed & 193 \\
\hline
\end{tabular}

There was no strict compliance related to providing any significant information, hence, difficulty in investigation 
for the MCA. With limited penal powers, MCA had capacity issues because of its organizational setup that were meant to be addressed. Nonetheless, in competition agency abilities of staff are quite dependent on economic regulation and conditions of the country. Thus, priority to competition law in government's agenda is affected by these aspects. Many countries around the world utilize various skills of lawyers, accountants and economists for evaluating cases. This determines the fact that MCA deals and suffers with unprofessional skills (Provisional Constitution Order, 2007). Absence of financial, human assistance and other infrastructure thus becomes another problem on random basis to pick up any issue for cases/analysis. All flaws determine that competition law was not prioritized by the government while formulating an economic agenda. Only few steps were taken in consideration to improve the ways of MCA. This transformation included the reorganization of MCA, train staff abroad through assistance of various donors, streamline the procedures and strengthen the capability of staff for achieving better output. With these necessary steps, ordinance of 1970 remained outdated and was requiring modernization to synchronize smoothly with the rapidly changing market economy. MCA did not serve any public interest and their efforts were not worth mentioning (Provisional Constitution Order, 2007).

From 1995-2005, following cases were dealt by MCA

\begin{tabular}{ll}
\hline Nature of Cases & No. of Cases \\
\hline Conversion of private limited companies into & 2 \\
public limited companies & \\
Divesture of excessive shareholdings & 1 \\
Inter-corporate financing & 23 \\
Merger & 3 \\
Monopoly power & 8 \\
Cartels & 4 \\
Registration of Prohibited agreements & 1 \\
False information & 3 \\
Non-compliance of authority's order & 1 \\
Non-compliance of request for information & 202 \\
Total order passed & 450 \\
\hline
\end{tabular}

\subsection{Third Phase: 2007-2009 (Competition Ordinance 2007)}

For developing a policy framework for new competition law a technical assistance program was requested by Government of Pakistan. All of this was a requirement to include new competition law, structure for to develop new competition agency for implementing law and for containing government policy statement. Thus, MCA and Ministry of Finance started to work with UK Department for International Development (DFID) and World Bank (WB). Because of all these efforts, MRTPO was replaced with Competition Ordinance 2007 (Competition Ordinance, 2007). MCA was dissolved and Ordinance 2007 established Competition Commission of Pakistan (CCP) for enabling law's proper functioning. On $12^{\text {th }}$ November 2007, a regulatory authority was introduced with mandate for working with independent quasi-regulatory, to develop competitiveness, protect consumers from any anti- competitive practices, and provide quasi-judicial body for creating a business environment with healthy competition to improve economic efficiency. MRTPO's deficiencies were corrected by Ordinance 2007 especially that of aspects related to definition, penalties, coverage and procedural matters. A state of emergency in November 2007 was and Provisional Constitutional Order (PCO) was issued in Pakistan whereby 1973's constitution of Pakistan was suspended (PCO, 2007).

On $15^{\text {th }}$ February 2008, PCO's validity was challenged by Supreme Court of Pakistan and a seven member bench endorsed it. Supreme Court on $31^{\text {st }}$ July, 2009 passed a judgment that declared PCO as unconstitutional. Inter alia, prior to the date of $15^{\text {th }}$ December 200736 ordinances that were promulgated, containing Competition Ordinance 2007, were in the need of an approval from the parliament within the span of 120 days. National Assembly tabled Competition Ordinance 2007 in the form of Competition Bill in October 2009. Though, it got deferred for a reason that there was suspension of parliamentary session after its term expiration in November 2009 (Hussain, 2010). 


\subsection{Fourth Phase:2009-2010 (Competition Ordinance 2009)}

On November 2009, Competition Ordinance 2007 was revalidated by President Asif Ali Zardari as per Article 89 of 1973's Constitution of Pakistan. According to this Article 89, President of Pakistan has the power to promulgate any ordinance if and only National Assembly or Senate is not in the session. Further, if the President finds these circumstances that he should be taking an immediate action then he can use his powers (The Competition Ordinance No XVI, 2010). This Ordinance will need an approval from Parliament within the span of 120 days. National Assembly on $27^{\text {th }}$ January 2010 passed this Competition Bill 2009. On $24^{\text {th }}$ February 2010, Competition Bill 2009 got tabled in the Senate. Senate after tabling it put forwarded this bill to Senate's Standing Committee on Finance for considering it in depth in addition to any recommended changes (The Competition Ordinance No XVI, 2010). Prior to all of this, in March 2009, a request was made to Ministry of Finance for starting promulgation process again for the Competition Ordinance 2009, due to the presence of lapse dated $26^{\text {th }}$ March 2010 and because of its unapproved decision from Senate. Thus, Commission became obsolete since there was a lapse present for the Ordinance. However, after being tabled in the National Assembly Competition Ordinance 2007 was now a Competition Bill in October 2009. Though, it was delayed to November 2009 for parliamentary session got suspended as it term came to a period of its expiration (Rahman, 2010).

\subsection{Final Phase: Transition from Temporary to Permanent (Competition Act 2010)}

Parliament of Pakistan, on $23^{\text {rd }}$ September 2010, unanimously approved Competition Act 2010. A transition period followed for the Competition Bill 2009 in October when it was presented Pakistan's National Assembly for parliamentary approval as it significantly moved towards a temporary phase to a permanent one (Rahman, 2010). Competition Act 2010 was designed for promoting a fair and competitive economic that outright was a field for an entire corporate sector, whilst protecting consumers and safeguarding economic efficiency due to the presence of anti-competitive practices and attitudes. The title adopted by Competition Act 2010 reflects scope and objectives of the law because it has an extensive application and is wider in scope than the former MRTPO 70 (The Competition Ordinance No XVI, 2010).

\section{Competition Law in China-Development and Progression Phase}

There lies great variation between the progression phases of Pakistan and China's competition law. It wasn't until 1987 that the legislation of the anti-monopoly law in China became commonly known that too after the former Legal Affairs Bureau of State Council's AML drafting team formally initiated the drafting of AML (Lubman, 2000). Erstwhile this, the under the economic expansion reforms and new openings in China, in order to end the territorial barrier and departmental blockade, on $1^{\text {st }}$ July 1980 the State Council broadcasted the Provisional Rues on Expediting the Economic Alliance (Donald, 2007). Furthermore, in order to promote healthy and smooth economic competition as well as to bring new reforms in the prevailing system, on $17^{\text {th }}$ October 1980 the State Council Provision launched the Socialist Competition. Following this on $23^{\text {rd }}$ March 1986 the third document was released aiming to further Expediting and Protecting Socialist Competition ( $\mathrm{Su}, 2009)$. These three documents are famously known as the most initial form of anti-monopoly law which was further intended towards breaking down the economic monopolies that were actively working previously following history (AML, 2000). Some of the most momentous milestones in anti-monopoly law legislation in China are as such:

- 1988: Anti-Unfair and Anti-Monopoly Competition Provisional Regulations was introduced

- 1993: On 1st December 1993 the NPC standing committee on its 8th session broadcasted the Anti-Unfair Competition law (AML, 2000).

- 1994: The 8th session of NPC standing committee also listed the AML in the legislation Plan. For this the former National Economic and Trade Commission and the State Administration for Industry and Commerce all collectively were appointed the task of drafting the AML; eventually by May the AML Draft Working Team and the AML Draft Steering Team were functioning (AML, 2004).

- 1997: In July the very 1st version of the AML Online Draft was launched.

- 1998: By the 9th Session of the NPC Standing Committee the AML was listed legally in the legislation. Whereas, following this in November the 2nd Version of the AML Outline Draft came about.

- 2000: Soliciting Opinion Version which was the 1st draft of AML was launched.

- 2003: By the 10th session of the NPC Standing Committee made the AML legislatively one of the fundamental economic legislation

- 2004: AML was listed in the State Council by the Ministry of Commerce submitted the AML (For Review Version) on 26th February. It was further listed in the legislation Plan by the State Council (Williams, 
2005).

- 2005: The NPC Standing Committee added the AML in the legislation plan, this is the same year when the State Council progressively made the AML Review and Modify Steering team, the AML Review, Modify Expert Team and the Modify Working Team were given the duty to look into the AML draft and to review as well as modify, working on the possible changes needed.

- 2006: the AML draft was revised brought into discussion, and finally by the State Council Executive Meeting the principle was passed. The State Council Executive Meeting further decided to take this to the NPC Standing Committee to look into the possible changes that were required or could have made it better by revising it ahead. From June 24th and 29th, the 10th session of the NPC Standing Committee sat again to revise the provisions of the AML draft. (Williams, 2005).

- 2007: Following this year two sessions were held, first in June during the 10th NPC Standing Committee read the second AML draft. Following this the second read of this year took place from August 24th to 30th.

- 2008: Finally, in this year the AML was imposed.

-AML Post is the AML Legislative Practice and Development/Landmark Judicial Judgments and Rulings.

- AML Legislative Practice and DevelopmentlLandmark Judicial Judgments and Rulings (Fox, 2007).

\section{Competition Law: An Overview of Some Important Features}

It has been a common practice since decades to explore competition law as much possible. There are many underlying questions trying to trigger the quest more and more, by every passing day, for instance, its origin, engraved ideas, how can this possibly benefit society in the best suited way possible and its role and participation in economic matters (Dabbah, 2010). In Modern Competition law, it is to be seen that any violation of the competition law does not harm an individual's rights. Different legal systems work to make sure that people have freedom to carry out trade and to guard them from all sorts of constraints which became the essential of competition law (Landolt, 2006).

The aim of Competition law is to make sure that there is a protected and healthy competition, the maximization of consumer benefit, further ensuring that consumers and producers are both in a healthy relationship, they have the freedom of choice and action relating to their trade, promoting healthy innovative competition and the resources are in the right hands. As it is a known fact that competitive regimes make sure that there is a healthy and aspiring competition which further increases the quality of products produced by the firms and the industries. Any sort of evolution in this area shows that it is never ending and there is always so much more one can do (Haq, 1974). Economic competition is very influential and is of great significance in matters of governance and growth as it aids in in upholding a very friendly growth and trade both regionally and internationally which further proves its significance (The Constitution of Pakistan, 1973). In Pakistan competition policy agenda is followed which promoted sustainable economic growth and public benefit. Thus far, we have been observing how significant the promotion of competition is. In China this branch of law to prevent the harmful growth of monopolistic economic trends, aiding in fair market competition, promoting economic growth, protecting their interests, making sure the society is in good progress and working for the progression of socialist market economy (Dabbah, 2010).

\subsection{Rational of Law}

The 2010's Competition law is the sub division of a wider competition policy. The characteristics and the agenda of this can further be found from these preambles:

- Enhancing economic competence

- Safeguarding the consumers from any fraud in anti-competitive market behavior.

- To gain maximum advantage of the productive competence (Landolt, 2006).

The former law was introduced with the agenda of providing measures against the unwarranted power, unfair monopolistic power and lastly limited trade boundary. As we have also discussed earlier that free competition, making sure that economic growth is progressing, and protecting consumers from anti-competitive behavior have always been the agenda behind all this, this law ensures a much better and broader scope in pro-competition as compared to MRTPO 70 (The Competition Ordinance No XVI, 2010).

Whereas, the aim of this law being an anti-monopoly law is to protect the rights and interest of enterprises in making sure they have free competition and maximum social welfare (Harris et al., 2011). This legislative will prove to be very beneficial especially in their growth and progress which is very important for economies like 
China which is very famously known as a transitional economy. This law will be seen acting if there is any panic in the market with regards to their economy. Just like this the AML has its own purpose towards the promotion of healthy competition among different companies including the industrial policies.

\subsection{Anti-Competitive Agreements in Pakistan and China}

The Competition Act 201045 explicitly outlaws any agreement that leads to a lessening of competition in a relevant market, be it formal or informal, written or oral. The Act encompasses any such agreement and the extent of the reduction in competition does not lead to any exemption and even the intent of the parties for such agreements to be legally binding does not hold significance (Wang The law and its provisions allow the CCP to not only specify and stipulate certain individuals but also block exemptions that arise from any such agreements as they may be detrimental to efficiency and economic transparency and merit. It is easier to ascertain the legality of any such agreements where they are found in writing. There are numerous issues, on the other hand, where any of the arrangements cannot be found in writing (Lin and Jingjing, 2012). Therefore, organizations, in a bid to evade the law, operate without writing and form institutions that can be termed cartels. The lack of material evidence that arises out of such informal arrangements is problematic. The enforcement of the law hinges then on the use of circumstantial evidence (Lin and Jinging, 2012). To substantiate a claim to the existence of any such agreement, witness testimonies are necessary for learning the medium through which the communication of information takes place inside these cartels and also offers an insight into the decisions that are made and the hierarchy through which they are made (Dabbah, 2010). Aside from this, the operation of such cartels has led enforcement agencies to devise other means of investigation. A method that has found particular appeal, similar to plea bargains, is the leniency program whereby individuals who act as whistle-blowers on their fellow cartel members. The use of the leniency agreement is sanctioned by the Competition Act 2010 where the Competition Commission of Pakistan can find a breach of Chapter 2 stipulations of the law by, thereby allowing the agency to provide lenient and less severe sanctions for those that act as informers (Competition Act, 2010). The competency and functioning of law enforcement agencies is crucial as to ensure that individuals in breach of the law feel compelled to collaborate (Competition Act, 2010).

Chinese law, on the other hand, does not preclude companies from exercising their intellectual property rights under the AML, but it does prohibit abuse of intellectual property by organizations and corporations which is aimed at affecting the existing levels of competition in the market (Zhang and Vanessa, 2010). However agricultural producers do not fall under the AML and any such rural economic organizations that delve into agricultural products, in any manner, including production, transportation, sales and transportation. The jurisdiction of the law extends to the territorial limits of China, which is all of mainland China (but not including Macau, Hong Kong and Taiwan), but it also is in force where any such activity would directly affect the competition in the Chinese market (Lin and Jingjing, 2012) thereby meaning the AML also has an extra territorial jurisdiction. It does not operate retrospectively and is only applicable after it was brought into force, which was the first of August, 2008 (Zhang and Vanessa, 2010). The actions that the AML renders unlawful, to protect competition in the market, are as follows: agreements are aimed at either restricting or eliminating competition, the abuse of power which arises out of a powerful and dominant position in the market (monopolization), any such individual transactions that may limit competition and the abuse of executive power for the same purposes (Deng and Cunzhen, 2013).

\subsection{Competitors Dealing}

The AML strictly forbids anti-competitive agreements and to make a list of these agreements so that they can find a way to get a way out of this permanently, like the ones where the prices are fixed, restricts the output and sale, limiting selling and purchasing markets, reduce purchase of new products or facilities, and especially the ones where we see group boycotts. Bid rigging is an example that is officially states in this but it still is entertained under this legislation (Wang, 2009).

\subsection{Dealings in Supply Chain: Resale Price Maintaince}

AML forbids anti-competitive alliances that fix the price of goods sold to the third parties calling it unfair and a hinder to the growth of market as well as competition. Including the limitation of the minimum value at which goods can be sold to any $3^{\text {rd }}$ party.

\subsection{Dealings in Supply Chain}

AML stops any company that has a very strong position at selling products at unreasonably high prices or even buying products at an unfairly low price. It has been declared illegitimate to any company that engages in any activity as such without having any legitimate justification. These also include: selling products at a reduced cost, 
refusal in making a deal, exclusive deals, and discrimination based on prices.

\subsection{Merger Review}

AML strictly restricts any form of merger transactions that are in any way anti-competitive, which might as a result have a negative impact on economy, by eliminating or restricting competition in any pertinent market (Healey, 2018; Huang, 2008).

In Pakistan, the vital enactment on merger control in section 11 of the Competition Act and the Competition (Merger Control) Regulation, alongside CCP merger rules. The Merger Regulation gives subtleties of the edges, exclusion conditions and merger strategies (stage I and II surveys), including the application type of pre-merger application. It records a few factors that the Commission will consider for the appraisal of the merger (Harris, 2011). These components incorporate the degree of import, simplicity of passage, level and patterns of fixation, level of countervailing power, attributes of the market, vertical reconciliation, bombing firm and the evacuation of dynamic contenders (Wang, 2009). The merger rules comprehensively explain the variables that the Merger Regulation alludes to under the headings of a piece of the pie, potential impacts of mergers (composed and nonfacilitated impacts), power of buyer, the probability of section, efficiencies and bombing firms (Wang, 2009).

\section{Comparision}

Competition Act Section 4 in Pakistan denies undertaking or association from going into any understanding or settling on any choice in regard of production, supply, distribution, securing or control of products or the management of services, which have impact of forestalling, confining or decreasing the competition inside the pertinent market except if absolved by the Commission. Such deals or agreements incorporate, yet are not constrained to, showcase sharing and value fixing of any kind; fixing amounts for creation, appropriation or deal; restricting specialized turns of events; just as deceitful offering or offering and the use of divergent conditions (Mangi, 2004). Be that as it may, the Competition Commission is engaged to approve exemptions. In China, The enforcing elite can arrange the organizations to quit it, take unlawful gains and force a fine of from $1 \%$ up to $10 \%$ of deals income (turnover not simply benefits) made in the earlier year (Mangi, 2004). By and by the business income is constrained to business in China. Moreover, as far as possible income considered to deals identified with the items that are the subject of the supposed unlawful direct (albeit nothing in the law expects it to do as such). On the off chance that branch workplaces of an organization are the gatherings that abused the AML, at that point the Chinese specialists limit deals income to the branch office instead of putting together it with respect to the united deals of the whole organization. In the occasion the anticompetitive understanding has not been actualized, the legislature can force a fine at the very least 500,000 RMB (Huang, 2008). Trade affiliations can be fined up to 500,000 RMB and where the conditions are "not kidding" (not characterized) the exchange affiliation might be deregistered. The administration may lessen the punishment or even choose not to force a punishment if an organization that was occupied with an anticompetitive understanding intentionally gives data about the understanding and gives "significant proof" (not characterized in the resolution) to the separate requirement office (Deng and Cunzhen 2013).

Backing for the view that there is a cozy connection among law and society can be found in rivalry law writing. Various creators have exhibited that a point by point investigation of the cultural setting of rivalry law is fundamental to understanding its plan and authorization, particularly in creating and changing nations (US Chamber of Commerce, 2010). They contend that scope of issues, for example, institutional abilities, the job of the state, legislative issues and another turn of events and strategy objectives impact the requirement of rivalry law in creating and changing nations, if not additionally it's content. These perceptions are additionally applicable to rivalry law in China and Pakistan, because, notwithstanding China's size, populace and quick development since setting out on monetary changes and opening up, Pakistan stays a creating nation and its market changes are viewed as deficient (Review Commission, 2015). While there are a few viewpoints like, for example, the massive size of the Chinese economy and population, it is significant financial and worldwide political impact and its long bureaucratic convention that separate China from Pakistan. In any case, China faces a portion of the difficulties that other creating and progress nations experience in embracing and upholding the opposition law, for example, constrained institutional abilities. Further, the drafters of the opposition law themselves perceived that, while it was critical to gain from other locales' encounters on rivalry law and for the AML to be reliable with global standards, the AML additionally expected to reflect and suit China's particular needs and conditions. While, notwithstanding conventional gauges, the opposition law in Pakistan should be clarified and comprehended by reference to its institutional, monetary and political settings, that is, the Chinese and Pakistani political economy. In Pakistan, Competition specialists are required to keep up a good and straightforward methodology in an effective procedure that is conceivable just if the Authority is protected from the undue political impedance. To this end, it 
is suggested that the Government of Pakistan surrender its power over the ordinary capacities and effective procedures of the position. The MRTPO did not give any capability models to the choice of the Authority, and accordingly, senior officials with no essential foundation have been posted in the MCA (Review Commission, 2015). The pioneers in any association can make and support the feeling of mission, energy and responsibility to satisfy the objectives of that association, and the equivalent is valid for the opposition authority. On the off chance that individuals from a disconnected foundation are presented on the opposition office, they will not have the option to contribute adequately to the structure procedure of the association, as they do not appreciate the quintessence of the association that is to advance the opposition culture (Wang, 2009). The Act 2010 sets down qualification rules for the arrangement of individuals from the board, the definitive forces however with respect to capability, experience and method of arrangement of the individuals are again presented on the government. The absence of an orderly methodology under the MRTPO ruined the examination of different parts of the economy (Huang, 2008). Subsequently, there have not been numerous examinations work/contemplates; consequently, the competition law couldn't prosper.

\section{Conclusion}

Generally, competition law is supposed to prevent anti competition rituals and practices by nurturing free and fair competition in the market. The researcher investigated mechanisms to evidences while applying leniency laws in both China and Pakistan. The study concluded that it promotes a greater competition in the market by safeguarding customers against inaccurate means, which are adopted by firms. Therefore, competition law can be regarded as highly essential for regulating businesses by ensuring producer and consumer welfare, it can be argued that the researcher achieved first research objective while exploring that leniency program in both Pakistan and China is in accordance with market structure. It ultimately promotes healthy growth of the economy and social justice. In accordance with that, competition law's system play its role in shielding competition's process by entailing a robust, powerful as well as independent competition. It would ensure improved and more impactful economic performance. If we make comparison of China and Pakistan's competition law, it can be argued that the Competition Act 2010 and AML set out 'the norms as well as principles of sound competitive behavior in such a way that these norms can be effectively implemented in the both countries but their leniency programs have administrative liabilities only. However, a legal framework is provided which helps create an effective and healthy business competition and environment. It leads to an improved economic efficiency through the development of competitiveness and protection of customers from anti-competitive norms and practices.

For improving the competition law's effective enforcement in both countries, following recommendations are provided in this research:

- It is important to have a transparent process of selection and recruitment. Quality should be focused more than quantity in order to appoint the authority's members. There should be the adoption of nondiscriminatory policy.

- It is highly recommended that appointment process design should assist the impartial and fair selection of people, who can play their role in sustaining political pressures. There should be clear rules for the selection committee which appoints members and chairperson under law. The committee shouldn't be under pressure of any political entity. Same as china members of the committee can be easily removed without any political influence if found guilty.

- A greater lesson should be learnt by the governments from previous law while relinquishing their influence on decision making process and regular functions of high ups by permitting them to do independent work.

- In the field of law, professionals or experts need to be engaged to provide research with regard to assisting the commission in terms of discharging their function on merit.

- Experts/professionals in the field of law should be engaged to assist the Commission in.

- Familiarizing students from law, economics, finance and management is very productive, since they would understand the importance and need of competition law and its provisions. Imparting knowledge and training related to it is highly crucial.

- In the field of competition law, greater initiatives need to be taken by offering provide internships to students.

- In the developed country like china, there should be arrangement of workshops in collaboration with various competition authorities with regard to planning as well as conducting inquiries into the restraints of trade, abuse of dominance, mergers and many other aspects related to competition law. 
- There should be mandatory consultation mechanism in both countries with competition authority in regulatory and legislative processes, which would great help them in the future ahead.

\section{References}

5S Rahman. (2010). Competition Law Comes into Force. The Dawn.

Allen, F., Qian, J., \& Qian, M. J. (2005). Law, Finance, and Economic Growth in China. Journal of Financial Economics, 57, 58-9. https://doi.org/10.1016/j.jfineco.2004.06.010

Anti-monopoly Law, Ch. II.

Chen, S. (2009). The Establishment and Development of the Chinese Economic Legal System in the Past Sixty Years.

Competition Policy Report. (2007). A Framework for a New Competition Policy and Law: Pakistan. The World Bank.

Dabbah, M. M. (2010). International and Comparative Competition Law. Cambridge University Press, Cambridge. https://doi.org/10.1017/CBO9780511777745

Daudpota, F. (2013). Anti-Money Laundering Law of Pakistan an Overview. SSRN Electronic Journal, 12 (3), 2233. https://doi.org/10.2139/ssrn.2368483

Deborah, H. (2008). An Anti-monopoly Law for China: Weapon or Mirage? Competition \& Consumer Law Journal, 220, 225-7.

Deng, F., \& Huang, C. Z. (2013). A Five Year Review of Merger Enforcement in China. The Antitrust Source, 1, 18.

Donald, C. C. (2007). Legislating for a Market Economy in China. The China Quarterly, 567. https://doi.org/10.1017/S0305741007001579

Eleanor, M. F. (2008). An Anti-monopoly Law for China - Scaling the Walls of Government Restraints. Antitrust Law Journal, 173.

Fatima, S. (2012). Competition Law In Pakistan: Brief History, Aspirations And Characteristics. Commonwealth Law Bulletin, 38(1), 43-62. https://doi.org/10.1080/03050718.2012.646734

H. Stephen Harris Jr et al. (2011). Antimonopoly Law and Practice in China. New York: Oxford University Press.

Haq, M. (1974). The Poverty Curtain: Choices for the Third World. Columbia University Press, New York.

Huang, Y. (2008). Pursuing the second best: The history, momentum, and remaining issues of China's antimonopoly law. Antitrust Law Journal, 75(1), 117-131.

Huang, Y. (2008). Pursuing the Second Best: The History, Momentum, and Remaining Issues of China's Antimonopoly Law. Antitrust Law Journal, 117, 127-8.

Hussain, D. (2010). Senate Body to Discuss Competition Bill. The Dawn.

L Nielson, A. (2018). The Paradox of Discretionary Competition Law. European Competition and Regulatory Law Review, 2(3), 156-165. https://doi.org/10.21552/core/2018/3/4

Landolt, P (2006). Modernized EC Competition Law in International Arbitration. Kluwer Law International, The Hague.

Lin, P., \& Zhao, J. J. (2012). Merger Control Policy under China's Anti-monopoly Law. Review of Industrial Organization, 109, 123-5. https://doi.org/10.1007/s11151-012-9345-9

Naween, A. M. (n.d.). Comment: Are Flourishing Cartels Reason Enough to Shut Down the Impotent MCA? Daily Times. Retrieved from http://www.dailytimes.com.pk/default.asp?page=story_23-12-2004_pg5_

Re-promulgation of Competition Ordinance: CCP Asks MoF to Start Process' Pakistan News Watch. 11 March 2010.

See Provisional Constitution Order No. 1 of 2007, issued 3 November 2007, amended 15 November 2007.

Stanley, L. (2000). Bird in a Cage: Chinese Law Reform after Twenty Years. Northwestern Journal of International Law \& Business, 383, 383-4.

The Competition Act No XIX of 2010. Published in the Gazette of Pakistan, Extraordinary, 13 October 2010. Hereinafter CA 2010. 
The Competition Ordinance No LII of 2007. Published in the Gazette of Pakistan, Extraordinary, 2 October 2007. CO 2007.

The Competition Ordinance No XVI of 2010 (published in the Gazette of Pakistan, Extraordinary, 20 April, 2010).

The Competition Ordinance No XVI of 2010.

Tikka Iqbal Muhammad Khan and others v General Pervez Musharraf [2008] PLD SC at 178.

US Chamber of Commerce, Competing Interests in China's Competition Law Enforcement, pp. 53-62.

US-China Economic and Security Review Commission, 2015 Report to Congress, p. 95.

Wang, X. (2002). The prospect of antimonopoly legislation in China. Washington University Global Studies Law Review, 201-232.

Wang, X. Y. (2009). The New Chinese Anti-monopoly Law: A Survey of a Work in Progress. Antitrust Bulletin, 577, 584-7. https://doi.org/10.1177/0003603X0905400303

Zhang, X. Z., Vanessa, \& Zhang, Y. H. (2010). Chinese Merger Control: Patterns and Implications. Journal of Competition Law and Economics, 477, 492-3. https://doi.org/10.1093/joclec/nhp029

\section{Copyrights}

Copyright for this article is retained by the author(s), with first publication rights granted to the journal.

This is an open-access article distributed under the terms and conditions of the Creative Commons Attribution license (http://creativecommons.org/licenses/by/4.0/). 